S sciendo

\title{
A CONCEPT OF BLDC DRIVE MODEL CONTAINING BATTERY CELL MODEL
}

\section{Michał Brodzicki1 ${ }^{1}$, Przemysław Chrabąszcz ${ }^{2}(\mathbb{0}$}

Polish Naval Academy, Faculty of Mechanical and Electrical Engineering, Śmidowicza 69 Str., 81-127 Gdynia, Poland; e-mail: m.brodzicki@amw.gdynia.pl, p.chrabaszcz@amw.gdynia.pl; ORCID ID: 10000-0002-0366-6292, 20000-0003-0196-957X

\begin{abstract}
The paper presents a concept of overall BLDC drive model. Target model will be improved with a functional model of battery cell, which is commonly used as a power supply for the drive. The paper shows previous achievements in form of a functional BLDC motor model. Also, simulation results are presented. These are the partial results, that aimed to verify the basic model's correctness as a basis of future developments. The procedure of power source selection presented in the article is vital to specify the technical parameters of modelled battery cell.
\end{abstract}

Keywords:

BLDC drive, electrical drives, electrical machines, hybrid power source, li-Ion batteries, supercapacitors.

Research article

(C) 2020 Michał Brodzicki, Przemysław Chrabąszcz This is an open access article licensed under the Creative Commons

Attribution-NonCommercial-NoDerivatives 4.0 license (http://creativecommons.org/licenses/by-nc-nd/4.0/) 


\section{INTRODUCTION}

BLDC (Brushless Direct Current) motor is a specific type of electrical machines, which is currently commonly used as a propulsion for many electrical vehicles. BLDC is in fact a combination of PMSM (Permanent Magnet Synchronous Machine) motor and an electronic device responsible for steering and powering up the motor. The typical structure of BLDC drive is presented in fig. 1.

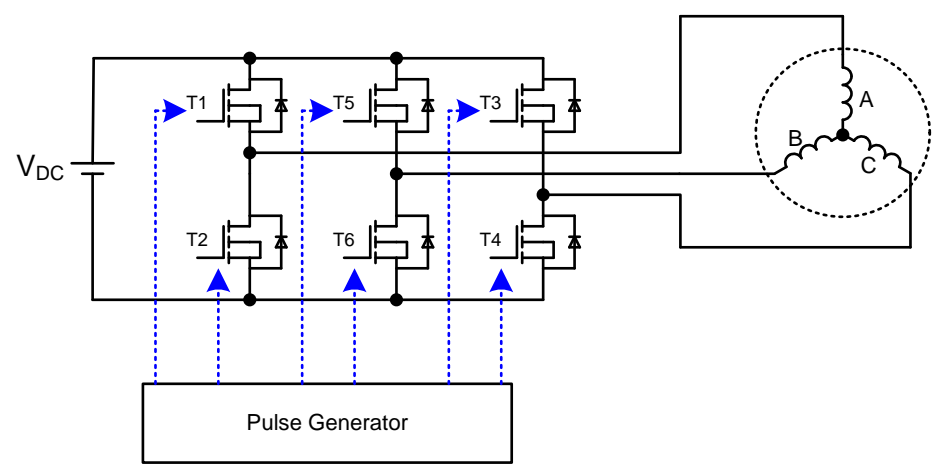

Fig. 1. Typical structure of BLDC motor $[4,6]$

PMSM motor itself is an AC machine, but as a consequence of electronic device application it can becomes a DC machine. This electronic device is a electronic controller, which can be considered as a commutator for the motor. The controller generates voltages that power up the motor. Generated voltages are square-type and are called the commutator functions, shown in the fig. $2[2,4,6]$.
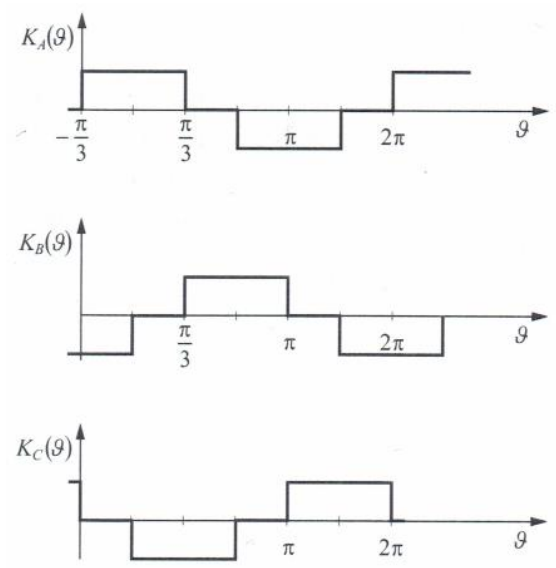

Fig. 2. Commutator functions for each BLDC motor phase [2] 
The controller has a bridge structure and is based on MOSFET transistors, which are controlled with externally generated pulses. PWM algorithm was not used in this basic model, but general concept allows its implementation. Consequently, voltages in the motor phases are specifically shaped, what affects the shape of EMF inducted in motor's windings. EMFs in BLDC motors are typically sinusoidal or trapezoidal $[1,3,5]$.

\section{SIMULATION MODEL OF BLDC MOTOR}

The model of BLDC motor was developed in Matlab/Simulink using predefined function block, which is an implementation of PMSM motor's mathematical model. The block was modified with specific values of windings' resistance and inductance along with mechanical parameters. Fig. 3 illustrates the final structure of the BLDC model.

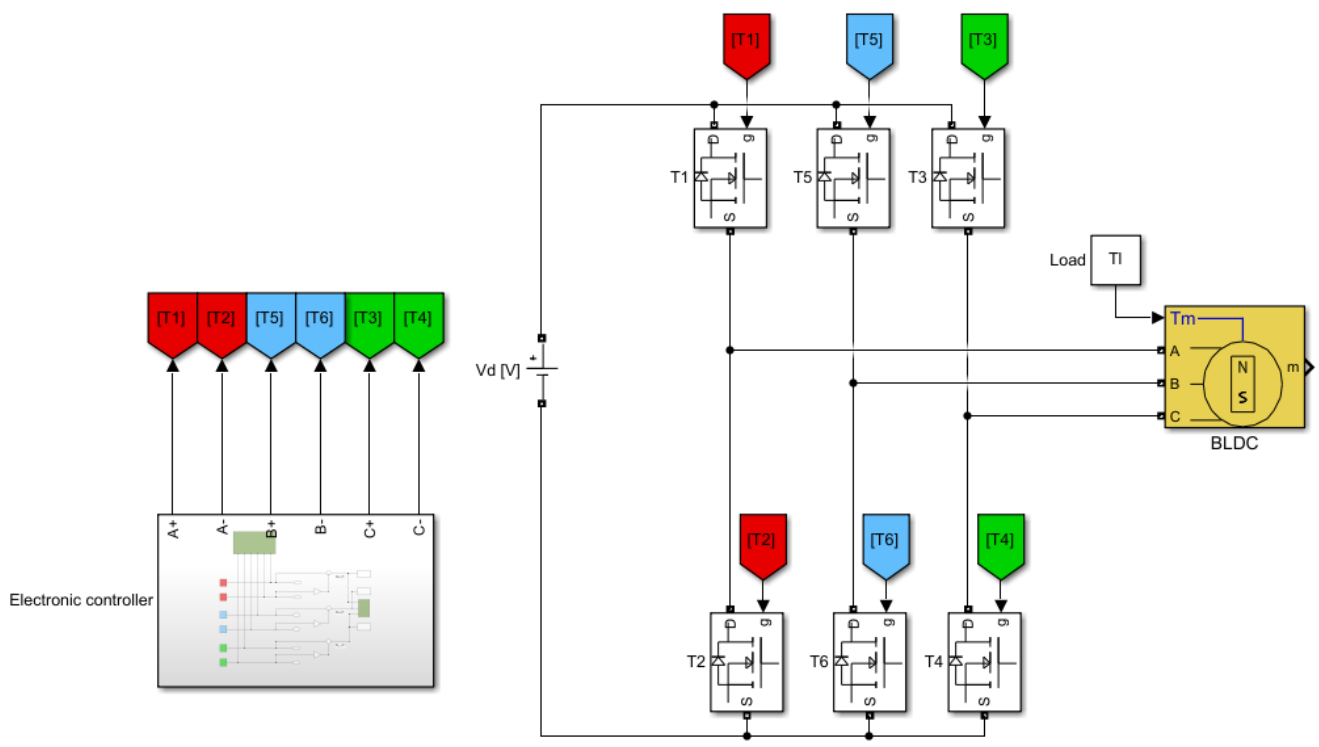

Fig. 3. Schematic BLDC motor model

The model represents a BLDC motor described with rated parameters shown in tab. 1. 
Tab. 1. Rated parameters of the modelled BLDC motor

\begin{tabular}{|c|c|c|}
\hline Parameter & Unit & Value \\
\hline Rated power & $\mathrm{W}$ & 1000 \\
\hline Rated voltage & $\mathrm{V}$ & $35-45$ \\
\hline Rated speed & $\mathrm{RPM}$ & 3000 \\
\hline Rated torque & $\mathrm{Nm}$ & 3 \\
\hline
\end{tabular}

The electronic controller model was developed individually using pre-defined blocks modelling MOSFET transistors. This represents the classic solution of electronic controller, while modern controllers are based on IGBT transistors. The model is a three-phase bridge powered by DC voltage source. Each transistor valve is switched with individual pulses generated externally. As a consequence, the voltages generated by the controlled are bipolar pulses, that fill the commutator functions presented in fig. 2 .

Whole model is combined with external file carrying the code for the simulation. Parameter definition and variables declaration is also done within the mentioned file. This solution allows parameters' modifications or non-complicated simulations' scenarios definition. What is more, the structural model can be also easily implemented to different BLDC motors parametrized with Matlab code files.

\section{SIMULATION RESULTS}

The developed BLDC motor's model was tested during a typical starting simulation. The scenario represented a start of a nominally loaded motor from zero to its rated speed. Simulation results are shown in fig. 4 and 5.

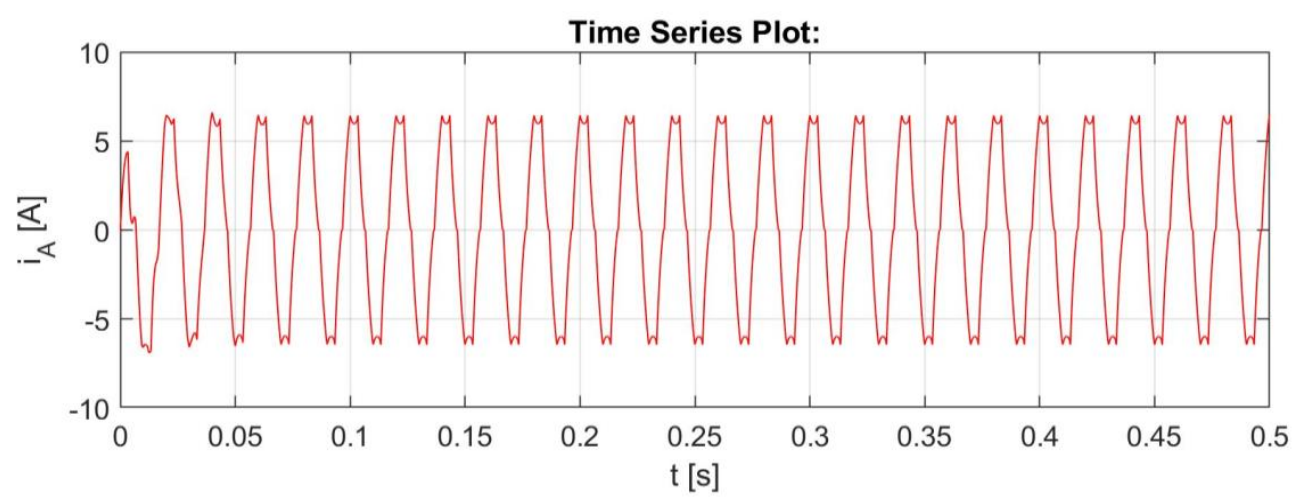

Fig. 4a. Illustration of motor current waveforms - phase A 


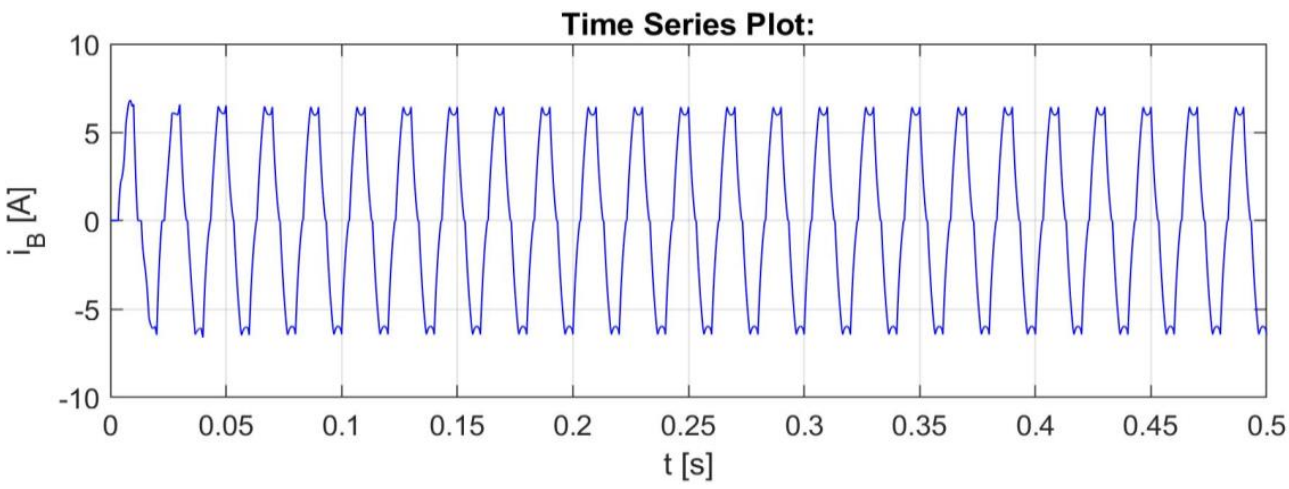

Fig. 4b. Illustration of motor current waveforms - phase B

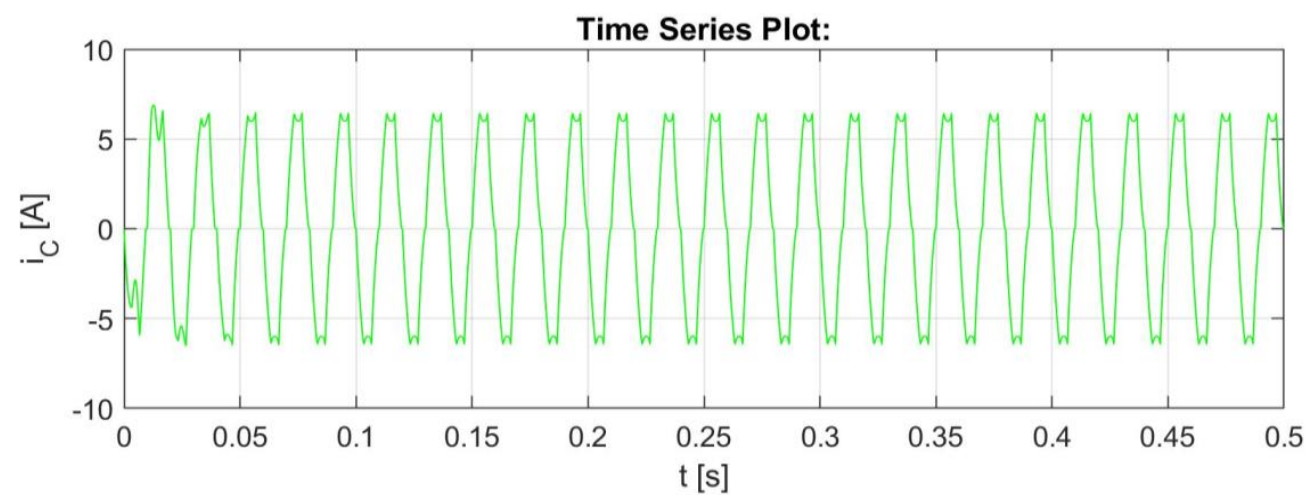

Fig. 4c. Illustration of motor current waveforms - phase C

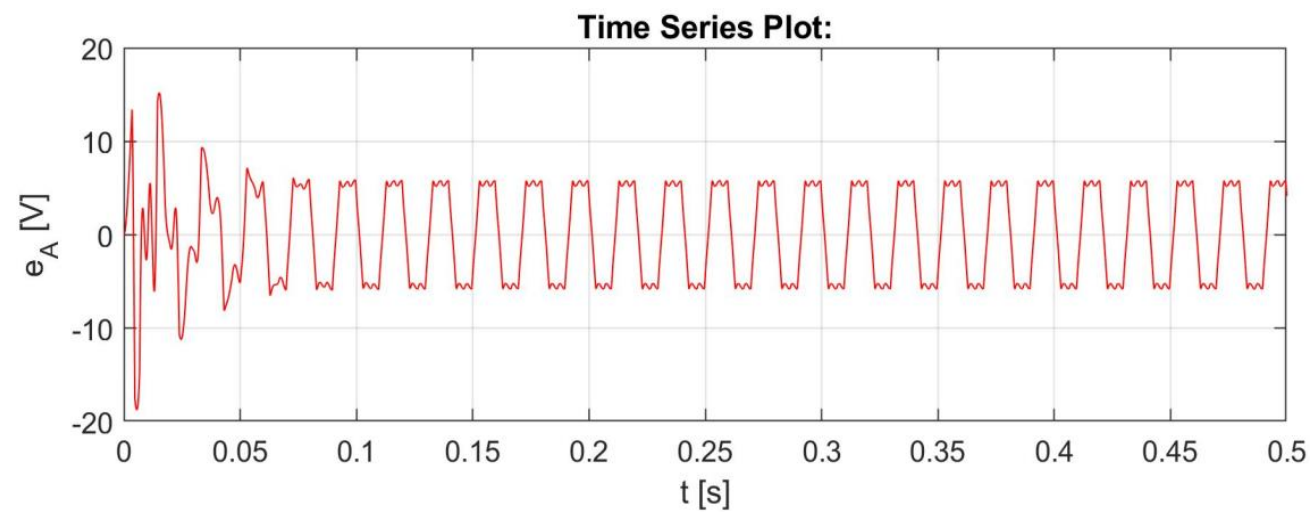

Fig. 5a. Illustration of motor EMF waveforms - phase A 


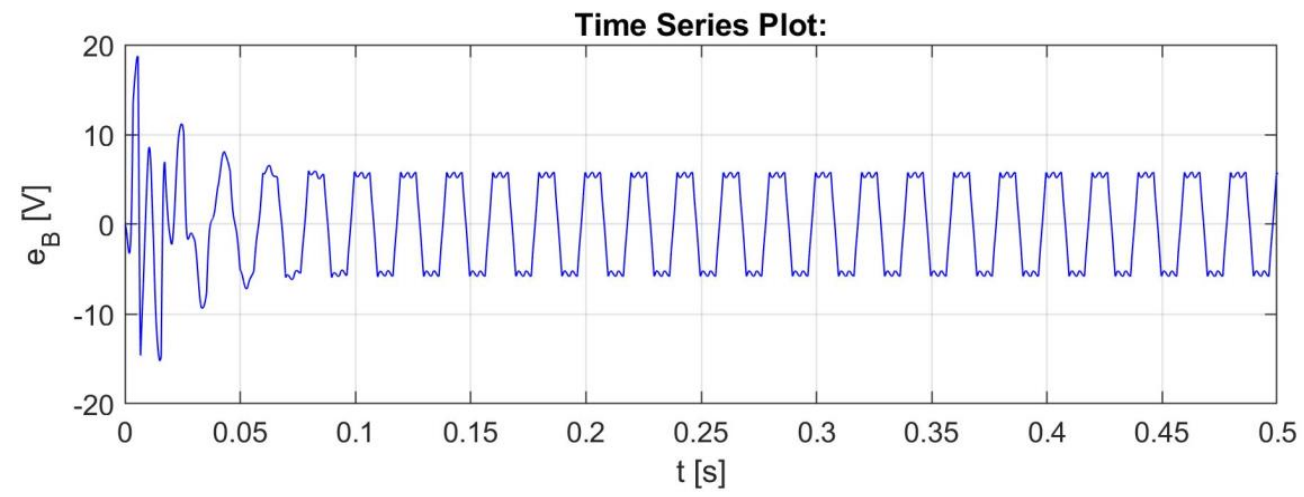

Fig. 5b. Illustration of motor EMF waveforms - phase B

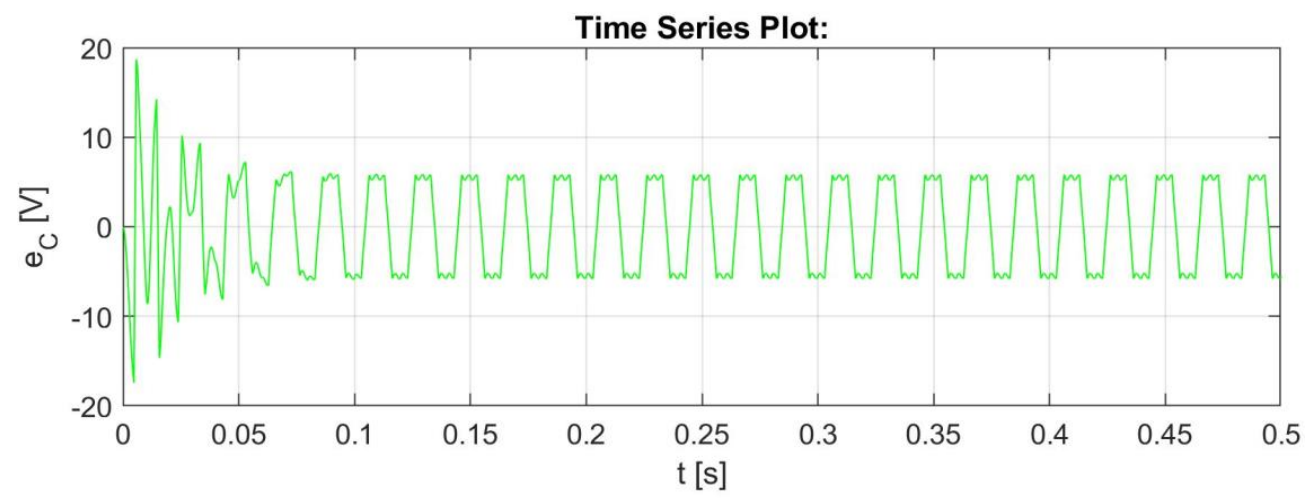

Fig. 5c. Illustration of motor EMF waveforms - phase C

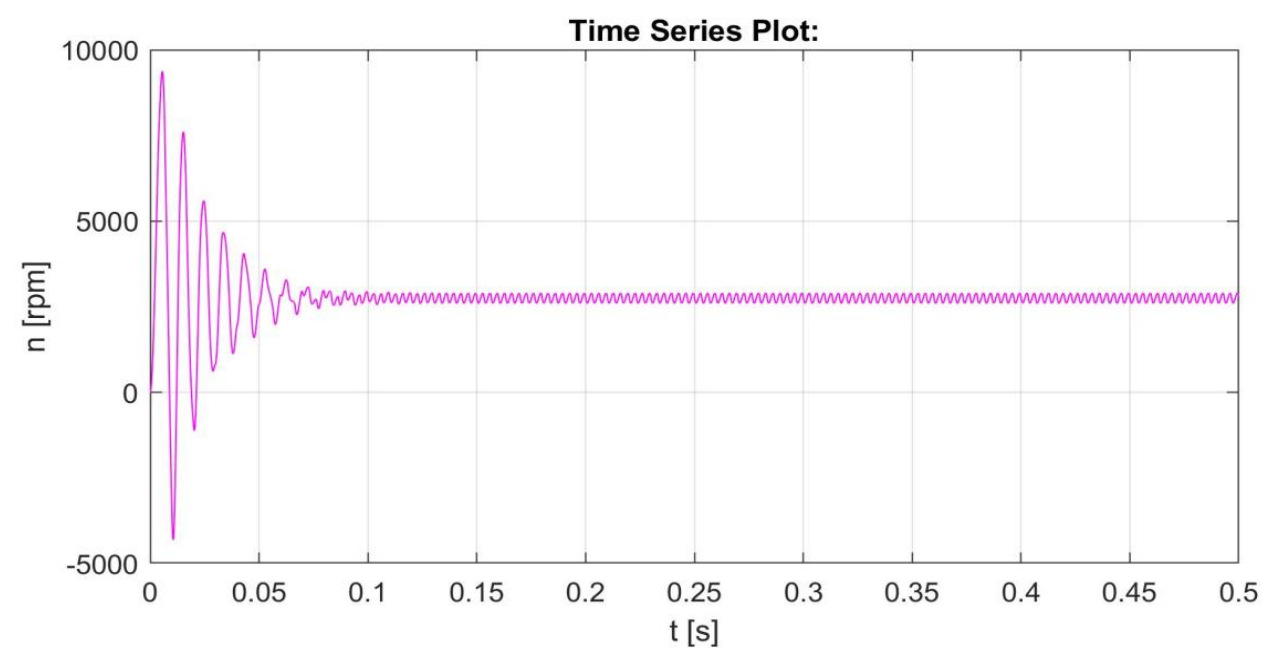

Fig. 6. Illustration of motor speed 


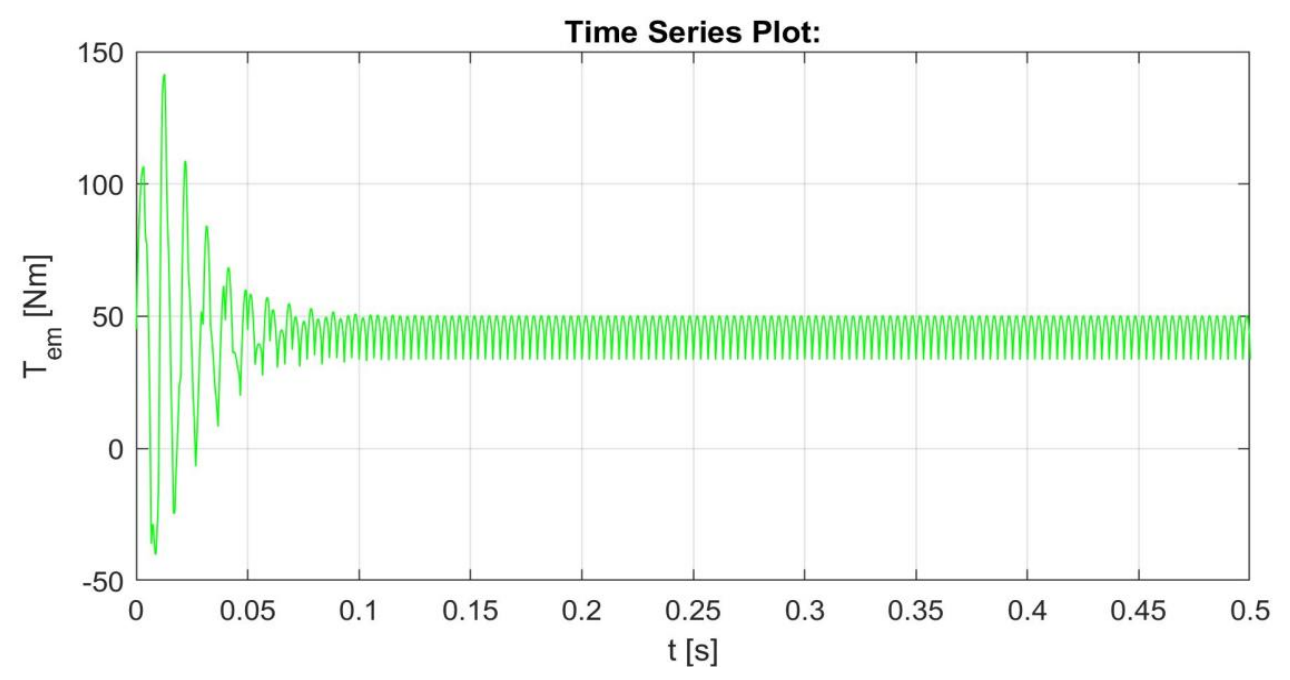

Fig. 7. Illustration of motor electromagnetic torque

Simulation results show, that model fulfils the assumptions. After short-time dynamic state the motor reaches its steady-state operating point. EMFs and currents stabilise and change periodically as a consequence of controller switching. Phase EMFs are trapezoidal what meets the assumption of trapezoidal shape. Result values derive from the model parameters and simulation scenario. Although the motor loading is equal to motor's rated torque, the drive starts as predicted and its further operation is stable.

All the resulting curves are bipolar, which is also a consequence of initial assumptions. All these facts show, that both the PMSM motor and controller models work correctly and represent the BLDC motor acceptably. Concluding, described basic BLDC model can be approved as a basis for further analysis and improvements. However, it is currently powered with ideal DC voltage sources, which is not affected by the drive itself. As a consequence, a specific scope of impacts is omitted. Thus, the model's crucial improvement should be the implementation of battery cell model as a power source for the whole BLDC drive.

\section{HYBRID POWER SOURCE - CONSTRUCTION GUIDELINES}

For the model of the engine adopted for the simulation, an energy storage should be designed in the form of a hybrid power source. The desired effect is planned to be achieved by combining electric energy sources in the form of batteries and 
supercapacitors in a way that allows their advantages to be used while minimizing the disadvantages and meeting the energy balance conditions.

As a result, tables were prepared with the outcomes of the preliminary calculations for power elements. That data will allow to determine the minimal number of key power source elements to achieve required nominal power. What's more, summaries of various technical parameters can be a source of data relevant to the prototype design of the device. At the stages of further development of the project, there may be a need to increase the drive power, and hence the efficiency of the source. Therefore, in order to obtain a comparative scale, it was included in calculations.

\section{THE HYBRID POWER SUPPLY CONCEPT}

In order to ensure uninterrupted high quality power supply, especially in situations of momentary high power demand (rapid acceleration, reversing), the galvanic cell battery will be supported by a supercapacitors modules (fig. 6). Due to the complexity of the charging and discharging control processes, the Battery Management System (BMS) must be applied. Widely available li-Ion chemical cells grouped in series packages of ten items $(10 \mathrm{~S})$ were taken into consideration.

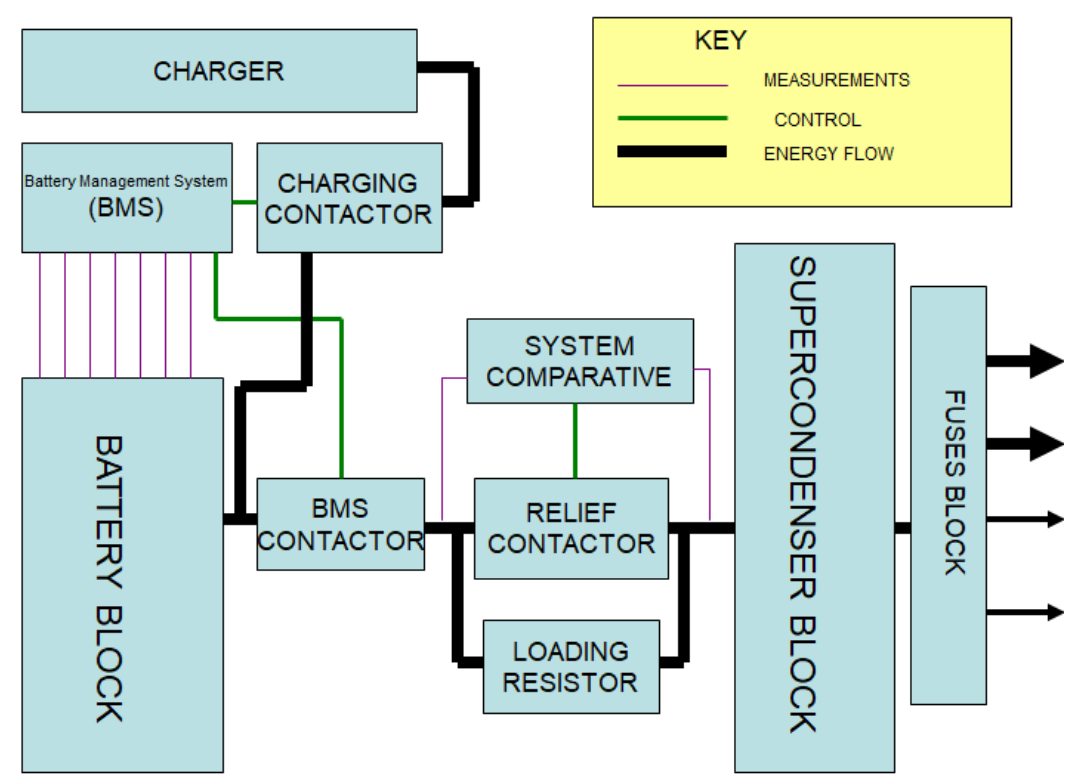

Fig. 6. Schematic diagram of a hybrid power source with protections (own studies and drawings P. Chrabąszcz) 


\section{PRELIMINARY PARAMETERS OF THE POWER SUPPLY SYSTEM PROJECT - ASSUMPTIONS}

1. The main energy receiver will be a $1 \mathrm{~kW}$ brushless electric motor powered by an electronic adapter.

2. The electric motor works at constant speed (speed stabilization) - the power drawn from the source is constant.

3. The bottom catalogue value was used as the battery voltage level.

4. Calculations were made for packs of serially combined batteries of 10 , based on data from catalogue cards.

5. To determine the volume occupied by cylindrical cells it was assumed that they are cuboids.

\section{SELECTION OF THE NUMBER OF BATTERY CELL PACKAGES}

Preliminary calculations were made based on cell manufacturers' data $[8,9]$. The obtained results allow to determine the extreme parameters of the constructed power source, including:

- the minimum impassable number of cells of a given type necessary to supply a specific power to the drive, meeting the condition of maximum current carrying capacity of each cell;

- minimal system operational times;

- mass and volume of the packages - allowing to determine the amount of space needed.

Tab. 2 and 3 present a summary of the parameters used in further analysis. The parameters in tab. 3 were calculated for $10 \mathrm{~S}$ packages.

Tab. 2. Input values for calculations of analysed cells [8, 9]

(own studies and calculations P. Chrabąszcz)

\begin{tabular}{|c|c|c|c|c|c|c|c|}
\hline Cell type & $\begin{array}{c}\text { Maximum } \\
\text { discharge } \\
\text { current } \\
{[A]}\end{array}$ & $\begin{array}{c}\text { Maximum } \\
\text { charging } \\
\text { current } \\
\text { [A] }\end{array}$ & $\begin{array}{c}\text { Nominal } \\
\text { Capacity } \\
\text { [Ah] }\end{array}$ & $\begin{array}{c}\text { Cell } \\
\text { volume } \\
{\left[\mathrm{cm}^{3}\right]}\end{array}$ & $\begin{array}{c}\text { Cell } \\
\text { weigh } \\
t[g]\end{array}$ & $\begin{array}{c}\text { Minimum } \\
\text { operating } \\
\text { voltage } \\
\text { [V] }\end{array}$ & $\begin{array}{c}\text { Nominal } \\
\text { voltage } \\
\text { [V] }\end{array}$ \\
\hline $\begin{array}{c}\text { NCR } \\
\text { 18650GA }\end{array}$ & 10 & 1.675 & 3.45 & 23.826 & 49.5 & 2.5 & 3.6 \\
\hline $\begin{array}{c}\text { ICR } \\
18650-26 A\end{array}$ & 5.2 & 2.6 & 2.6 & 23.826 & 47 & 2.75 & 3.7 \\
\hline
\end{tabular}

$1-2(220 / 221) 2020$ 
Tab. 3. Input values for calculations of analysed $10 \mathrm{~S}$ cell packs $[8,9]$ (own studies and calculations P. Chrabąszcz)

\begin{tabular}{|c|c|c|c|}
\hline Cell type & $\begin{array}{c}\text { Nominal operating } \\
\text { voltage } \\
\text { of the packet 10S } \\
\text { [V] }\end{array}$ & $\begin{array}{c}\text { Minimum packet } \\
\text { operating voltage 10S } \\
\text { [V] }\end{array}$ & $\begin{array}{c}\text { Maximum working } \\
\text { voltage of the 10S } \\
\text { packet (after charging) } \\
\text { [V] }\end{array}$ \\
\hline NCR 18650GA & 36 & 25 & 42 \\
\hline ICR 18650-26A & 37 & 27.5 & 42 \\
\hline
\end{tabular}

Based on the preliminary data from tab. 2 and 3, power packs were calculated for the most adverse operating conditions - near-discharge packs. In addition, calculations were made regarding the number of cells necessary for an adequately longer operational time of the source with a given input power. The results are shown in tab. 4-7.

Tab. 4. Extreme values for designing a hybrid power source for 10S NCR 18650GA battery cells for the minimum possible operating voltage of $25 \mathrm{~V}$ resulting from the maximum current carrying capacity of each cell (own studies and calculations P. Chrabąszcz)

\begin{tabular}{|c|c|c|c|c|c|c|c|c|}
\hline 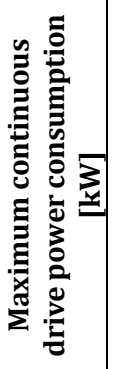 & 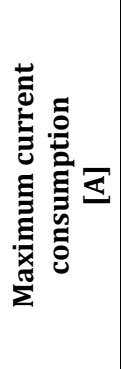 & 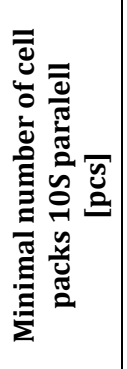 & 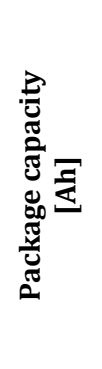 & 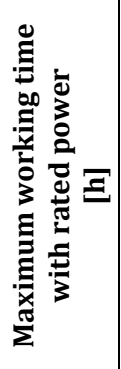 & 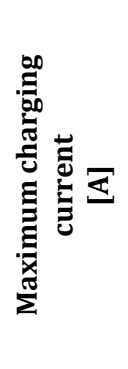 & 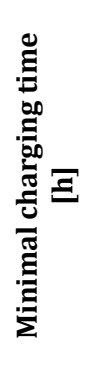 & 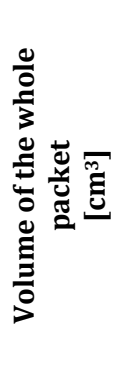 & 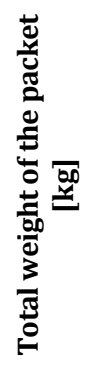 \\
\hline 1 & 40 & 4 & 13.8 & 0.35 & 6.70 & 2.06 & 953 & 1.98 \\
\hline 2 & 80 & 8 & 27.6 & 0.35 & 13.40 & 2.06 & 1906 & 3.96 \\
\hline 4 & 160 & 16 & 55.2 & 0.35 & 26.80 & 2.06 & 3812 & 7.92 \\
\hline
\end{tabular}

Tab. 5. The minimum total number of $10 \mathrm{~S}$ cell packages of the NCR 18650GA type for a given operating time at a specific constant power consumption (own studies and calculations P. Chrabąszcz)

\begin{tabular}{|c|c|c|c|c|}
\hline $\begin{array}{c}\text { Maximum continuous } \\
\text { drive power consumption } \\
{[\mathbf{k W ]}}\end{array}$ & $\begin{array}{c}\text { 1h [number } \\
\text { of sets 10s] }\end{array}$ & $\begin{array}{c}\text { 2h [number } \\
\text { of sets 10s] }\end{array}$ & $\begin{array}{c}\text { 3h [number } \\
\text { of sets 10s] }\end{array}$ & $\begin{array}{c}\text { 4h [number } \\
\text { of sets 10s] }\end{array}$ \\
\hline 1 & 12 & 23 & 35 & 46 \\
\hline 2 & 23 & 46 & 70 & 93 \\
\hline 4 & 46 & 93 & 139 & 186 \\
\hline
\end{tabular}


Tab. 6. Extreme values for designing a hybrid power source for ICR 18650-26A batteries for a minimum operating voltage of $27.5 \mathrm{~V}$ resulting from the maximum current carrying capacity of each cell (own studies and calculations P. Chrabąszcz)

\begin{tabular}{|c|c|c|c|c|c|c|c|c|}
\hline 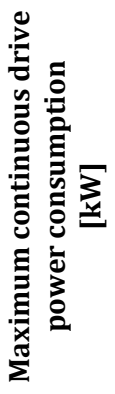 & 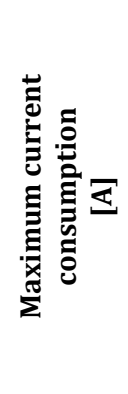 & 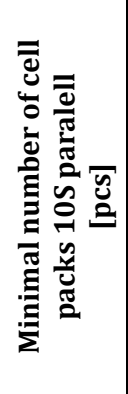 & 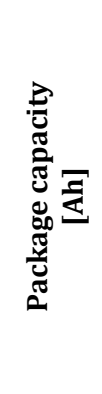 & 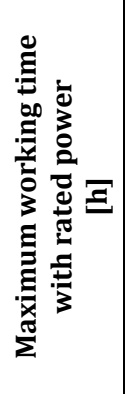 & 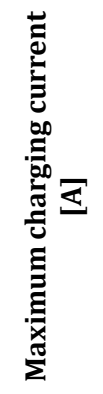 & 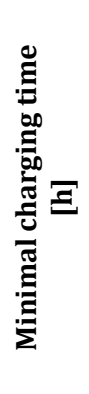 & 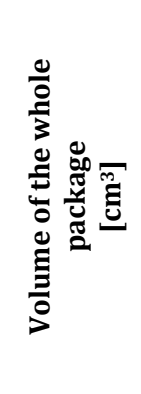 & 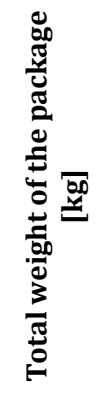 \\
\hline 1 & 36.36 & 7 & 18.18 & 0.50 & 18.18 & 1.00 & 1666.15 & 3.29 \\
\hline 2 & 72.73 & 14 & 36.36 & 0.50 & 36.36 & 1.00 & 3332.31 & 6.57 \\
\hline 4 & 145.45 & 28 & 72.73 & 0.50 & 72.73 & 1.00 & 6664.62 & 13.15 \\
\hline
\end{tabular}

Tab. 7. The minimal total number of 10S ICR 18650-26A cell packages for a given operational time at a specified constant power consumption (own studies and calculations P. Chrabąszcz)

\begin{tabular}{|c|c|c|c|c|}
\hline $\begin{array}{c}\text { Maximum continuous } \\
\text { drive power consumption } \\
{[\mathrm{kW}]}\end{array}$ & $\begin{array}{c}\text { 1h [number } \\
\text { of sets 10S] }\end{array}$ & $\begin{array}{c}\text { 2h 1h [number } \\
\text { of sets 10S] }\end{array}$ & $\begin{array}{c}\text { 3h1h [number } \\
\text { of sets 10S] }\end{array}$ & $\begin{array}{c}\text { 4h1h [number } \\
\text { of sets 10S] }\end{array}$ \\
\hline 1 & 14 & 28 & 42 & 56 \\
\hline 2 & 28 & 56 & 84 & 112 \\
\hline 4 & 56 & 112 & 168 & 224 \\
\hline
\end{tabular}

While selecting devices powered from the hybrid power source, one should take into account the wide voltage range of the battery $(36-42 \mathrm{~V})$, resulting from the voltage characteristics of Li-Ion cells [8] (own studies, drawings and calculations P. Chrabąszcz).

\section{SELECTION OF SUPERCONDENSORS FOR HYBRID POWER SUPPLY - PRELIMINARY CALCULATIONS}

Knowing the maximum currents taken from the Li-Ion cell battery and the maximum operating voltage of the power source, it is possible to select supercapacitors for the hybrid power source. The role of capacity in this system is to reduce 
the chemical cell load at peak and momentary consumption, thanks to which the nominal currents can be taken in the calculations, and then in the BCM settings. The input parameter in the designed system will be the maximum cell ampacity.

Peak currents were assumed - in the form of short-term pulses (not longer than $5 \mathrm{~s}$ ) at the level of $150 \%$ of the rated current. Single supercapacitors are available for low supply voltages. Importantly, exceeding the low allowable operational voltage of individual cells can cause their damage with further effects. In order to obtain higher operating voltages, supercapacitors are connected in series, at the expense of a decrease in their capacity. As a result of the occurrence of the leakage phenomenon, unequal distribution of voltages on individual cells may occur, and eventually some of them may be damaged. To prevent this, special voltage equalization systems, called balancers, should be used. Supercapacitors are characterized by equivalent series resistance (ESR), which defines their ability to quickly accumulate and give off energy. While the phenomenon of rapid energy release is beneficial for our power source, as it compensates for the momentary rapid demand of loads, the speed of energy storage is not. After parallel connection of the supercapacitors package to the accumulator battery, it will be necessary to connect a resistor with the appropriate resistance in series, which will limit the current flowing from the galvanic source. The values of this current will depend on the previously designed power pack as well as the parameters set in BMS, the exceeding of which will cut off the power source. A resistor limiting the charging current (fig. 6) will be necessary when applying power to the capacitors - after the packages are turned off by BCM or after service work. The value of the resistor is best selected by experimenting, and the calculated values included in tab. 8 should be used as the reference point. The current threshold above BMS is $110 \%$ of the rated current In, adequate to the nominal power of the drive.

Tab. 8. The value of supercapacitor charging resistor matched to the current efficiency of chemical cells, below the BMS protection threshold

(own studies and calculations P. Chrabąszcz)

\begin{tabular}{|c|c|c|c|}
\hline \multicolumn{4}{|c|}{ Resistor limiting the capacitor charging current at maximum voltage (42V) } \\
\hline $\begin{array}{c}\text { Nominal current In } \\
\text { [A] }\end{array}$ & $\begin{array}{c}\mathbf{1 1 0 \%} \text { In } \\
{[\mathbf{A}]}\end{array}$ & $\begin{array}{c}\mathbf{R}=\mathbf{U} / \mathbf{I} \\
{[\mathbf{\Omega}]}\end{array}$ & $\begin{array}{c}\text { Resistor strength } \\
{[\mathbf{W}]}\end{array}$ \\
\hline 40 & 44 & 0.955 & 1628 \\
\hline 80 & 88 & 0.477 & 3256 \\
\hline 160 & 176 & 0.239 & 6512 \\
\hline
\end{tabular}

Based on the sample catalogue data of individual cells [7], tab. 9. contains a summary of useful parameters for supercapacitors after battery assembly. 
Tab. 9. List of parameters of considered supercapacitors individually and after assembling into a battery [7] (own studies and calculations P. Chrabąszcz)

\begin{tabular}{|c|c|c|c|c|}
\hline Capacitor type & bcap1200 & bcap1500 & bcap2000 & bcap3000 \\
\hline Capacity [F] & 1200 & 1500 & 2000 & 3000 \\
\hline Nominal voltage [V] & 2.7 & 2.7 & 2.7 & 2.7 \\
\hline maximum current [A] & 930 & 1150 & 1500 & 1900 \\
\hline Single cell weight [g] & 260 & 280 & 360 & 510 \\
\hline Single cell volume [cm3] & 272.7 & 313.2 & 375.8 & 508.5 \\
\hline ESR [m $\Omega]$ & 0.58 & 0.47 & 0.35 & 0.29 \\
\hline The number of capacitors to obtain 42V [pcs] & 16 & 16 & 16 & 16 \\
\hline Package Capacity 43.2V [F] & 75 & 93.75 & 125 & 187.5 \\
\hline ESR 16S [ $[$ ] & 0.0093 & 0.0075 & 0.0056 & 0.0046 \\
\hline Package load 14S Q $=\mathrm{C}^{*} \mathrm{U}[\mathrm{C}]$ & 2775 & 3469 & 4625 & 6938 \\
\hline Package Weight $16 \mathrm{~S}[\mathrm{~g}]$ & 4160 & 4480 & 5760 & 8160 \\
\hline Package Volume 16S [cm $\left.{ }^{3}\right]$ & 4362.5 & 5011 & 6013 & 8135 \\
\hline
\end{tabular}

\section{PROTOTYPE POWER APPLICATION PROSPECTS}

Further considerations should include the requirements of dimensions, weight and operational conditions of the hybrid power source. The concentration of a large number of galvanic cells in combination with supercapacitors located in a small space of the device carries some risks. A large number of batteries with a certain efficiency, and therefore specific energy losses during charging and discharging may be the reason for raising the temperature in the power supply range above the permissible for the work of given cells, which can have dangerous consequences. In addition, a power source failure (spontaneous short circuit or even a small flooding with water) consisting of several dozen to a thousand galvanic cells with highly reactive and combustible lithium, supported by supercapacitors capable of generating a short-circuit current of a thousand amperes, may result in a fire, explosion causing injuries to personnel and losses in the environment.

\section{REFERENCES}

[1] Ciurys M., Dudzikowski I., Analiza bezszczotkowego silnika prąu stałego z magnesami NdFeB, 'Maszyny Elektryczne - Zeszyty Problemowe', 2011, No. 93, pp. 143-147 [Analysis of a brushless DC motor with NdFeB magnets — available in Polish]. 
[2] Glinka T., Maszyny elektryczne wzbudzane magnesami trwałymi, WNT, Warszawa 2018 [Electrical machines excitated by permanent magnets - available in Polish].

[3] Hubik V., Toman J., Singule V., BLDC motor control design in Matlab/Simulink, 'Maszyny Elektryczne - Zeszyty Problemowe', 2010, No. 88, pp. 35-39.

[4] Krykowski K., Silniki PM BLDC - właściwości, sterowanie, aplikacje, Publ. BTC, Legionowo 2015 [PM BLDC motors - properties, control, applications - available in Polish].

[5] Popenda A., Modelling of multiphase BLDC motor, 'Przegląd Elektrotechniczny', 2018, Vol. 94, No. 1, pp. 85-88.

[6] Zajkowski K., Duer S., Diagnostyka silnika BLDC i układu sterowania, 'Autobusy', 2012, No. 5, pp. 530-536 [BLDC motor and control system diagnostics - available in Polish].

[7] K2 ULTRACAPACITORS - 2.7V SERIES, [online], https://www.maxwell.com/images/documents/ k2series_ds_10153704.pdf [access 02.04.2020].

[8] Samsung $26 A 18650$ Battery, [online], http://www.batteryonestop.com/baotongusa/products/ datasheets/li-ion/Samsung-SDI-ICR18650-26A.pdf [access 02.04.2020].

[9] Specifications for NCR18650GA, [online], https://www.orbtronic.com/content/Datasheetspecs-Sanyo-Panasonic-NCR18650GA-3500mah.pdf [access 02.04.2020].

\section{KONCEPCJA MODELU NAPĘDU Z SILNIKIEM BLDC UWZGLĘDNIAJĄCEGO MODEL BATERYJNEGO OGNIWA ZASILAJĄCEGO}

\section{STRESZCZENIE}

Artykuł przedstawia koncepcję całościowego modelu napędu z silnikiem BLDC. Prototyp docelowy będzie uwzględniał w pełni funkcjonalny model ogniwa bateryjnego stanowiącego popularne źródło zasilania dla napędów z silnikami BLDC. W pracy zawarto dotychczasowe osiągnięcia w postaci funkcjonalnego modelu silnika BLDC wraz z wynikami badań symulacyjnych. Stanowią one wyniki cząstkowe, które miały na celu weryfikację poprawności opracowanego modelu silnika BLDC jako podstawy do dalszej rozbudowy. W artykule przedstawiono zasady doboru źródła zasilania dla prawidłowego określenia parametrów technicznych modelowanego ogniwa.

\section{Słowa kluczowe:}

napęd z silnikiem BLDC, napędy elektryczne, maszyny elektryczne, hybrydowe źródło zasilania, akumulatory li-ion, superkondensatory.

Article history

Received: 03.04.2020

Reviewed: 02.05.2020

Revised: $\quad 13.05 .2020$

Accepted: $\quad 05.06 .2020$ 